\title{
Refugees after Long Distance Migrating and Camping: Secondary Wound Infection Etiology and Management (Original research)
}

E. Kalavsky (Erich Kalavsky)5 ${ }^{5}$ V. Krcmery (Vladimir Krcmery)3, V. Kozon (Vlastimil Kozon)4 ${ }^{4}$ M. Jackuliakova (Maria Jackuliakova)2, A. Liskova (Anna Liskova)², J. Otrubova (Jana Otrubova)², M. Belovicova (Maria Belovicova)2, L. Janovicova (Lucia Janovicova) 1,2, B. Durcova (Barbora Durcova)1,2, L. Matulnikova (Ludmila Matulnikova)2, A. Naddour (Annemarie Naddour)2, Y. Trilisinskaya (Yanna Trilisinskaya)2, T. Simonek (Tomas Simonek)1,2

${ }^{1}$ UNHCR camp Lesbos, SEU Migrant Health Program,

Original Article

Kykinos Foundation, Lesbos, Greece

2 St. Lesley College Nove Zamky, St. Neumann College, Pribram, Czech Republic

${ }^{3}$ Institute of Microbiology, Comenius University, Bratislava, Slovakia

${ }^{4}$ Allgemeine Krankenhaus, Vienna, Austria, College of Polytechnics, Jihlava, Czech Republic

${ }_{5} \mathrm{MSc} /$ Nutrition Program Kuala Lumpur, Malaysia

\section{E-mail address:}

tropicteam@gmail.com

\section{Reprint address:}

Tomas Simonek

UNHCR Camp

Lesbos

Greece

Source: Clinical Social Work and Health Intervention

Volume: 9

Issue: 4

Pages: $68-71$

Cited references: 2

\section{Reviewers:}

Andrea Shahum

UNC Chapel Hill, NC, USA

George Benca

House of Family, Phnom Penh, Cambodia

\section{Key words:}

Refugee. Migrant Health.

\section{Publisher:}

International Society of Applied Preventive Medicine i-gap 


\section{Abstract:}

Refugee and migrant health issues are still of major concern in Greece, Italy and other countries of the Mediterranean area. The aim of this study is to compare etiology of wound infections in two groups - illegal migrants and refugees; those traveling by foot and camping in nature via BiH to Croatia, Slovenia and Austria (Group A) versus those crossing the sea from the Turkish coast to Lesbos Island (GR).

\section{Introduction}

Migrant and refugee health are major concerns within the European Union since Sept. 2015 until now. This is because from Sept. 2015 to March 2016, 1.1 million refugees and migrants $(\mathrm{RM})$ crossed the Turkish/Greek border and migrated via the Balkan Route to Germany, Scandinavia, Austria and other Western EU destinations. Those migrants in the first wave had been transported by trains and buses from Athens across Greece through Thessaloniki and Idomeni border posts to Serbia, Croatia, Hungary or Slovenia. Our Refugee and Migrant Health Teams have offered health assistance to more than 917,000 migrants within the last 3 years, where the majority traveled only 1-3 weeks. After the Idomeni border post had been closed legal migration was stopped. However, smaller numbers of illegal migrants were continuing their path to the Western EU by foot, hiking and camping in free nature from April to October 2016, 2017, 2018; several thousand of RM have been backed up in Macedonia (FYROM), Kosovo, Albania (AL), Bosna and Herzegovina $(\mathrm{BiH})$. Commonest complication after hundreds of miles of hiking and camping in sub-standard situations in free nature are a variety of wounds and in children pneumonia. (1.2)

The aim of this study is to compare etiology of wound infections in two groups illegal migrants and refugees, those travelling by foot and camping in nature via $\mathrm{BiH}$ to Croatia, Slovenia and Austria (Group A); versus those crossing the Mediterranean Sea from Turkish coast to Lesbos Island (GR).

\section{Patients and Methods}

Two groups of migrants, 61 in total, 1 negative culture from wild camp (ICRC) at the Bosnian/ Croatian Border, and 1 on the Turkish/Greek border (the regular UNHCR Camp Lesbos); both with 30 wound infections were cultured; swabs from wounds analyzed for etiology and antimicrobial resistance and tested in National Ref Lab of Antimicrobial Resistance in Nitra; at the Slovak Tropical Institute in Bratislava; or the Institute of MC at Comenius University School of Medicine. Both groups were also compared concerning antimicrobial with local or systemic therapy given to refugees and migrants.

\section{Results and Discussion}

Both groups showed similar etiology concerning gram-positive organisms. However, differences in gram-negative rods: the proportion of $S$. aureus and Str. pyogenes as major wound pathogens were similar, the proportion of MRSA among $S$. aureus was between $20-40 \%$ which is much higher than in host populations. Concerning gram-negaive rods, after $1,000 \mathrm{~km}$ trail hiking and free nature camping those from Bosna had more Enterobacteriaceae and 
Ps. aeruginosa, but those traveling a short time via the Mediterranean Straits between Lesbos and the Turkish coast had more marine organisms (ABBA-Acinetobacter baumanii and non aeruginosa Pseudomonas spp (P.stutzeri, P.fluorescens, P.putida, $P$ (B) cepacia), Leclercia adecarboxylata,, Aeromonas salmonicida, Stenotrophomonas maltophilia).

Table 1 shows significant differences ( $p$ o.0123) in proportion of gram-positive cocci (S. aureus Str. pyogenes) in favor of IRC Bosna) versus more marine organisms at the UNHCR Camp Lesbos island. Our previous observations for mainland Greece in 2017 $(1,2)$ also have shown more marine organisms from the respiratory tract and skin swabs in physio, and gym and other sports facilities in UNHCR Veria and Alexandria Camps due to the high proportion of "sailing" migrants and refugees. The sea environment was more frequently represented in respiratory tract colonizers, and in the current study also in wound pathogens or colonizers (1.2).

\section{Conclusions}

Migrants and refugees sailing from Turkey to Greece are concentrated in Lesbos UNHCR Camp and have significantly more gram-negative microorganisms including marine species such as non aeruginosa Pseudomonas (P.putida, P.(B)cepacia, P.fluorescens, P.stutzeri, A.salmonicida etc.) in comparison to those in Bosna after hiking and marching thousands of kilometers in the Balkan woods, who present more frequently with human classic pathogens such as S.aureus and Str.pyogenes. Resistance to betalactamas in S.aureus varied between $20-40 \%$ which is higher than in host populations. Also, the spectrum of Candida spp yeast wound colonization and/or infection was different non-albicans Candida spp were more frequent among refugees from the sailing group in contrast to C.albicans, which was prevalent among hikers in Bosna.

Table 1: Etiology of wound isolates from Refugees and Migrants in Lesbos UNHCR Camp (CK). Comparison to mainland $(\mathrm{BIH})$

\begin{tabular}{|l|c|c|}
\hline A) Classic human pathogens: & $\begin{array}{c}\text { \# of isolates } \\
\text { (GK) }\end{array}$ & $\begin{array}{c}\text { \# of isolates } \\
\text { (BIH) }\end{array}$ \\
\hline S. aureus total & 6 & 21 \\
\hline MRSA & 2 & 7 \\
\hline MSSA & 4 & 14 \\
\hline S. pyogenes & 3 & 1 \\
\hline Enterobacteriaceae & 5 & 3 \\
\hline B) Marine \& environmental organisms & & \\
\hline Ps. aeruginosa & 5 & 8 \\
\hline Acinetobacter & 2 & 4 \\
\hline Non aeruginosa Pseudomonas spp & 2 & 16 \\
\hline Other (Aeromonas salmonicida, Leclercia decarboxylata) & 0 & 2 \\
\hline
\end{tabular}




\section{References}

1. BELOVICOVA M, LISKOVA A, HRINKABATOVA J, TKACOVA L, MURGODOVA T, HULKOVA V, POLONOVA J, VA A, BYDZOVSKY J, TOPOLSKA A, LACA P, KILIKOVA M, KALATOVA D, BUCKO L, PALENIKOVA M, LISKOVA GALLOVA A, BAK T, SPANIK S, BUA, TOMIC L, CERVENA L, KHALIL I, JDOVA N, KRCMERY V, KOLEDA P, OLAH M, NADOUROVA A, HEINECKE HEIDEROVA H, HERDICS G (2017) Migrants Are Colonized by Resistant Bacteria S, ZOLLER K (2017) Low Prevalence of During Their Prolonged Stays in Refugee MRSA in Physiotherapy and Gym Facilities in a Greek Refugee Camp. In Clinical Social Work and Health Intervention vol. 8 Pages: $35-37$.

2. HAJJ ALI P, SASVARY F, KRCMERY $\mathrm{V}$, JANKECHOVA M, PUTEKOVA S, Camps. In: Clinical Social Work and Health Intervention Vol. 8, nr. 1. pages 15-19.

Acknowledgement: Supported by APVV Grant from the Slovak govt and ministry of education (LFUK,UCM) 